\title{
SHARING ECONOMY AND THE SOCIAL-ECONOMIC CONTEXT: MERCENARISM OR COMMON GOOD? ${ }^{1}$
}

\author{
ALINE D. R. LAZZARI ${ }^{2}$ \\ (D) https://orcid.org/0000-0002-1542-0281 \\ MAIRA PETRINI \\ (iD) https://orcid.org/0000-0002-3914-2589 \\ ANA CLARA SOUZA ${ }^{2}$ \\ (iD) https://orcid.org/0000-0001-5574-2560
}

To cite this paper: Lazzari, A. D. R., Petrini, M. , \& Souza, A. C. (2021). Sharing economy and the social-economic context: Mercenarism or common good? Revista de Administração Mackenzie, 22 (4), 1-28. doi:10.1590/1678-6971/eRAMG210001

Submission: Jan. $2^{\text {nd }}, 2020$. Acceptance: Oct. $1^{\text {st }}, 2020$.

1 This study was financed in part by the Coordenação de Aperfeiçoamento de Pessoal de Nível Superior Brasil (CAPES) - Finance Code 001.

2 Pontifical Catholic University of Rio Grande do Sul (PUCRS), Porto Alegre, RS, Brazil.

\section{(c) $\mathbf{B Y}$




\section{ABSTRACT}

Purpose: The aim of this research is to understand how the social-economic context influences the transformative potential of the sharing economy (SE).

Originality/value: The literature on SE is still fraught with uncertainty. We have found that there is a paradox between generating social benefits to the community versus increasing social inequality.

Design/methodology/approach: Data were collected from documentary analysis, netnography, participant observation, and interviews. The data collected were analyzed in the light of the theoretical framework proposed by Wittmayer et al. (2019) for the analysis of narratives related to social innovation.

Findings: The produced narratives differ in terms of the type of platform (profit and non-profit). We have found that, in non-profit platforms, the economic and social context does not influence the transformative potential guided by the SE; for-profit platforms, on the other hand, the narrative of 'income opportunity' is context-sensitive. The main contributions of the research are the use of a theoretical framework of social innovation to analyze the narratives of the SE and the observation of contextual differences about the phenomenon, which should lead platforms and governments (in their regulatory role) to have different views on SE. We conclude that the narratives of the SE are different. For-profit platforms either do not take part or contribute very little to the phenomenon of social innovation as a transformative process and, in the contexts of greater social-economic vulnerability, it can be a mechanism of worsening social inequality.

\section{KEYWORDS}

Sharing economy. Social innovation. Narratives. Context. Platform. 


\section{INTRODUCTION}

The sharing economy (SE) represents a new concept that changes the way people interact and already shows it is not a fragile or temporary movement (Parente, Geleilate, \& Rong, 2018), nor is it only associated with companies that have become globally known. The SE boom began in 2008, in a time of economic crisis. Since then, the phenomenon has been growing and attracting the attention of scholars and experts in the face of several questions about its characteristics and purposes. The new business models at SE represent an estimated 20-fold growth in 10 years, from 15 billion USD in 2015 to an estimate of 335 billion USD in 2025 ( PricewaterhouseCoopers, 2015), a projection also noted by Barnes and Mattsson (2017) and Muñoz and Cohen (2017). Uber, for example, in 2017, already operated in more than 70 countries and its market value, estimated at 70 billion USD, positioned it as the world's most valuable private technology company (Dudley, Banister, \& Schwanen, 2017). Both Uber and Airbnb are companies that represent the rapid growth of SE (Schor, 2017).

SE may be understood as the sharing or transaction of peer-to-peer goods and services, known as prosumers - it is a combination of the English words provider and consumer) (Palos-Sanchez \& Correia, 2018). The transaction takes place in a peer-to-peer format and is mediated by a technology platform. The SE is also fraught with controversy, one of which lies in the ambivalence between the social and economic character of companies linked to this type of economy (Cockayne, 2016). On the one hand, SE is seen as an alternative to sustainable development, on the grounds that it optimizes the use of idle resources and promotes social transformation (Avelino et al., 2015; Mont, Neuvonen, \& Lähteenoja, 2014). On the other hand, it is criticized for the claim that its benefits are purely economic, being just another income opportunity for those who participate in it (Habibi, Davidson, \& Laroche, 2017; Milanova \& Maas, 2017). For some authors, the social and environmental benefit is a side effect, but an important one (Cohen \& Kietzmann, 2014; (Cohen \& Kietzmann, 2014; Daunorienė, Drakšaitė, Snieška, \& Valodkienė, 2015). However, there are dangerous side effects, to the point that SE is called by Morozov (2013) "steroid neoliberalism", because it exacerbates the worst capitalist practices due to the lack of regulations, leading to the precariousness of labor relations. The widespread access provided by the SE is still limited since the less favored populations do not have digital access (Ganapati \& Reddick, 2018). The inequality resulting from SE 
is a relevant concern that needs to be further investigated (Schor, 2017). That is, the SE is understood as a means of access to income for individuals, indicating a potential contribution to social transformations, and it is also understood as a means of increasing social inequality, on the grounds that the richest people and platform owners are fundamentally the most favored by this "new" economy. Additionally, the literature points out that the social-economic context can, directly and indirectly, interfere in the perception of the value of the parties involved in SE (Dreyer, Lüdeke-Freund, Hamann, \& Faccer, 2017), but little is known about it. Considering the issues highlighted, this article seeks to identify:

- How does the social-economic context influence the transformative potential of the SE?

Studying the differences and similarities of the discourse of sharing is one of the possibilities to understand the economic and social effects of SE (Cockayne, 2016). Thus, to answer the aforementioned question, the transformative potential of SE will be investigated through narratives that constitute it socially. The analysis of narratives offers insights and knowledge, expanding the understanding of the social (Bastos \& Biar, 2015).

When conducting a study in the field of SE, Frenken, and Schor (2017) state that it is relevant to try to understand why different parties attribute different meanings to the phenomenon. The search for this understanding may be linked to social practices and discursive positions. Thus, the narratives of change appear, which are defined as "ideas, concepts, metaphors, discourses or stories about change and innovation" (Wittmayer et al., 2019, p. 2). Change narratives are used to identify the reason, the parties, and the way through which social change occurs (Wittmayer et al., 2019). To meet this research goal, this study used the theoretical framework proposed by Wittmayer et al. (2019) that, associated with the perspective of social innovation, allows identifying the reason, the players, and the context in which social changes occur and if they occur. Four different techniques were used to collect the data: 1. documentary analysis, 2. Netnography, 3. participant observation, and 4 . interviews.

In the sense of constructing the proposed analytical path, we started the discussion on the meaning of SE; then we discuss the narratives to finally get to the methodology, analysis, and discussion. Ultimately, we systematize the discussion in the final remarks. 


\section{SHARING ECONOMY}

SE can be understood as sharing goods, products, or services among people who do not know each other. This sharing occurs in the peer-to-peer format, in which a technological platform performs the intermediation of the transaction (Belk, 2014; Benoit, Baker, Bolton, Gruber, \& Kandampully, 2017). The parties involved in this transaction are called prosumers, a term derived from the combination of the English words provider and consumer (Palos-Sanchez \& Correia, 2018). The term prosumer arises because there is no need for intermediation between consumers and suppliers, that is, communication between supplier and consumer can occur directly. Thus, the supplier has the opportunity to understand and, consequently, better meet the need of this consumer. Ritzer (2015) states that, in this concept, it is often difficult to identify who is the supplier and who is the consumer since they change their position frequently. The sharing economy favors this direct communication between suppliers and consumers. SE is composed of non-profit and for-profit companies, which attract great popular attention. Uber and Airbnb are iconic examples of for-profit companies. As an example of non-profit companies, we can mention the Banco de Tempo (system of exchange of goods and services for time), CouchSurfing (hospitality service), and Freecycle (platform for exchanging objects).

The appreciation of companies linked to SE has surpassed companies long established in the sectors, not only of tourism and transportation but also in other segments, such as education, finance, workspaces etc. (Ganapati \& Reddick, 2018). Along with the high market valuation, SE platforms have also become objects of controversy, questioning the common good. In other words, the SE presents rhetoric of economic, social, and environmental benefits to those who participate but veiledly exacerbates capitalism, increasing social inequality (Schor, 2017). To illustrate this perspective, Murillo, Buckland, and Val (2017) point out that $75 \%$ of Airbnb rents come from entire homes, moving away from the essence of SE to share the same space by renting an idle room. Thus, SE, in reality, benefits a more privileged class. Also, according to the authors, SE promotes monopolies: Kickstarter (a crowdfunding site that seeks to support innovative projects) is responsible for $57 \%$ of crowdfunding transactions; Craigslist (online communities that deliver free ads to users) accounts for $65 \%$ of professional services; Uber is responsible for $86 \%$ of ride-sharing; and Etsy (e-commerce of handmade items) is responsible for $91 \%$ of the custom products market. Such companies dominate the market, enhancing an unequal distribution of wealth. 
The effects of SE are much more complex due to its externalities: the impact on the traditional market, smaller gains for workers, neighbors who feel uncomfortable with home rents and the presence of strangers, income distribution, and unequal well-being, among others (Freken \& Schor, 2017). Such externalities lead to an increase in social inequality, increasingly reinforcing the dominant structures.

SE can be highlighted, according to Lazarevic and Valve (2017), as a new form of consumption in which new business models enjoy a portion of the market to increase their profits, as well as in traditional businesses. Considering the transactions brokered by SE platforms, they apparently do not differ from the traditional economy because its main objective is to carry out financial transactions between people, bringing salespeople closer to consumers (Hou, 2018). The accumulation of revenue via SE increases the concern with inequality, mainly because the owners of the platforms and the richest people in the exchange relationships are the largest holders of the gains. Thus, it is necessary to broaden the understanding of the differences between the actors linked to SE (Gerwe \& Silva, 2018). SE apparently presents a community approach but actually generates devaluation of work (Cockayne, 2016).

At the same time that the externalities of the SE demonstrate their perverse side, research in economic and social contexts of greater vulnerability points to its potential as a job opportunity and access to income. Dreyer et al. (2017) analyzed the SE in South Africa, an emerging economy and a country with high levels of inequality, poverty, unemployment, and crime. By comparing two models of platforms (Uber and SweepSouth) to traditional businesses (taxis and SweepSouthand), the authors showed that, with the arrival of SE, the population began to have access to previously non-existent opportunities: access to cars, smartphone, internet, and the possibility of generating income, producing positive consequences for society. Guo, Xin, Barnes, and Li (2018) show that Uber creates about 50,000 new job opportunities globally each month, giving people the ability to generate income during their free time. Davidson, Reza, and Laroche (2018), by comparing the role of SE in North America and India, show that Americans seek transformative experiences, while Indians seek efficiency and convenience. It should be emphasized that, although the SE is global, the interests are different according to the context.

The literature is rich in controversies and uncertainties about SE, especially regarding its externalities and the paradox between job opportunity and access to income versus the increase in social inequality, reinforcing the 
dominant economic model. To discuss these issues, the narrative study is a way to understand the ways a story is constructed, for whom, and why. This is the path we will take in order to understand how the economic and social context influences the transformative potential of SE.

\section{NARRATIVES AND NARRATIVES OF CHANGE}

The narrative analysis allows different social players to be contemplated in different contexts and is useful to understand what occurs in social life (Bastos \& Biar, 2015). The narrative can be understood as a social practice, a way to build reality. With this, narratives are part of social practices, because they take different forms and generic forms that are closely related to the macro processes and practices that constitute them (De Fina \& Georgakopoulou, 2008). To understand social life, it is necessary to see the narrative as a form of knowledge, a form of social life, and a form of communication (Czarniawska, 2000). The narratives may vary according to the players, time, and space, as they are considered habitual and stable in a given environment. What positions the narrative scenario is the context, fundamental to its understanding (Wittmayer, Backhaus, Avelino, Pel, \& Kunze, 2015).

In a perspective of transition and change in social life, we find the definition of "narratives of change" as an integral part of social innovation, here considered from the conception of the European Union, according to which the social dimensions of innovation allow us to face pressing social challenges, including poverty, lack of equity and social justice. Through the narratives of change, it is possible to obtain information about "why the world has to change, who has the power to do this and how it can be done" (Wittmayer et al., 2015, p. 8). That is, they are a particular discursive form that positions players in a context and orders events or activities in the temporal sequence toward a goal or future.

The study of these narratives should focus on the main narratives, those that appear more frequently or that are repeated (De Fina \& Georgakopoulou, 2008). The study of change narratives indicates how change can be brought and contributes to a better understanding of transformative change. Social change can be defined as the "process in which new social practices emerge and become socially accepted and disseminated in society by processes of imitation, adaptation and social learning" (Howaldt \& Schwarz, 2016, p. 58). It is from social practice that innovations are incorporated by society. It positions this practice, therefore, as a central element when we talk about trans- 
formative change (Howaldt \& Schwarz, 2016). The context has a central role in the analysis of narratives; we seek to understand its relationship with the transformative potential of SE.

Wittmayer et al. (2019) proposed an analysis framework with the objective of capturing ideas about transformative change in narratives. Because of the alignment of perspectives, the framework (Figure 3.1) by Wittmayer et al. (2019) was used as reference support for analysis to answer the research question of this study.

\section{(Figure 3.1)}

\section{THEORETICAL FRAMEWORK FOR ANALYSIS NARRATIVES OF CHANGE}

\begin{tabular}{|c|c|c|}
\hline $\begin{array}{l}\text { Content of } \\
\text { narrative }\end{array}$ & $\begin{array}{l}\text { Why does the world have } \\
\text { to change? (Rationale) } \\
\text { Who are the relevant actors? } \\
\text { (Actors) } \\
\text { How is the desired future } \\
\text { achieved? (Plot) }\end{array}$ & $\begin{array}{l}\text { What are the current problems? } \\
\text { What is the desired future? } \\
\text { Whom are the actors working towards the desired } \\
\text { future? } \\
\text { Who are the actors opposing or counteracting the } \\
\text { desired future? } \\
\text { What developments and activities lead to the } \\
\text { desired future? } \\
\text { When and where do these take place? }\end{array}$ \\
\hline $\begin{array}{l}\text { Role of } \\
\text { narrative }\end{array}$ & $\begin{array}{l}\text { What role do narratives of } \\
\text { change play in the social } \\
\text { change process? }\end{array}$ & $\begin{array}{l}\text { What roles do social innovation initiatives ascribe } \\
\text { to their narratives/narrative practices? } \\
\text { What roles do narratives of change of social } \\
\text { innovation initiatives play in processes of societal } \\
\text { transformation? }\end{array}$ \\
\hline $\begin{array}{l}\text { Narrative } \\
\text { construction }\end{array}$ & $\begin{array}{l}\text { How are narratives of } \\
\text { change constructed? }\end{array}$ & $\begin{array}{l}\text { What activities do actors engage in to construct } \\
\text { a shared narrative of change? } \\
\text { How do narratives of change relate to dominant } \\
\text { societal narratives? } \\
\text { How is narrative construction mediated by } \\
\text { information and communication technologies and } \\
\text { infrastructures? }\end{array}$ \\
\hline
\end{tabular}

The first topic of the framework, the content of narrative, aims to structure the narratives, identifying their justification, the players, and the plot. The justification of the narrative consists in understanding the current situation and the desired future. Players (human or non-human) are those who support or oppose the desired future, collaborating or hindering social change. Players can be classified by their role as a supporter, beneficiary, or protagonist 
of change, among others. Finally, the plot is the way of organizing narratives to understand "how" the process of social change occurs.

The framework considers how the role of narratives is perceived in the processes of social change, highlighting three major roles:

- Changing scenarios: they are instruments used in an attempt to question the status quo and dominant beliefs. According to Davies (2002), these narratives can be termed as expressions of counterculture).

- Forming identity: the narrative assumes the role of forming the individual or collective identity, according to the development of history, that is, when forming identity, empowerment occurs. Thus, the narratives create the feeling of belonging to a group, generating common social meaning and the expectation for a future.

- Guiding the action: through the intertwining of stories, the narratives trigger the imagination, inviting us to think about the future.

In the analysis of narrative construction, the questions aim to identify how the social is constructed. Not only through stories and discourses, but technologies as a form of communication also have influence in this construction. This stage focuses on identifying divergent narratives and main narratives, which are the narratives that appear frequently.

Understanding the relevance of narratives and considering the application of the framework of Wittmayer et al. (2019) for the proposed analysis, we describe below the method used in this research.

\section{METHOD}

To answer the research question, an exploratory research was carried out (Gil, 2008), whose data were qualitative in nature, and a constructivist approach was applied (Schwandt, 2000). According to Wittmayer et al. (2015), by applying this type of approach in narrative analysis, it is possible to understand how the social production and the processes of change of society occur, in addition to providing direct analysis of narrative content.

Data were collected from four techniques.

- Documentary analysis, with the objective of contemplating the narratives of practitioners and academics who research the theme of SE, carried out through reports published by consulting companies, research institutes, seminars etc. (we analyzed 14 reports issued between 2015 and 2018). 
- Netnography (Costello, McDermott, \& Wallace, 2017; Kozinets, 2015), carried out from March 2018 to February 2019, with the objective of contemplating the narratives of platforms and users linked to SE. Organizations were selected based on the following criteria: platform in peerto-peer format, includes for-profit or non-profit platforms; access to data, the websites and social networks of organizations that present discourses linked to the SE were considered. Thus, five platforms were selected: Airbnb, OuiShare, Banco de Tempo from Porto Alegre, Blablacar, and Dinneer.

- Participant observation in an event linked to the sharing economy called ColaborAmerica.

- Interviews with managers and users of SE platforms. The choice of the interviewees sought to contemplate for-profit and non-profit platforms in which they are protagonists, acting as managers of the platform or user and, in some way, benefiting from the SE. Eight interviews were conducted, including managers and users (Figure 4.1).

It is important to highlight that the different data sources applied provided the authors with the opportunity to analyze different actors and contexts.

(Figure 4.1)

PROFILE OF INTERVIEWS

\begin{tabular}{llll}
\multicolumn{1}{c}{ Platform } & \multicolumn{1}{c}{ Interviewed } & Duration & Reference \\
\hline \multirow{2}{*}{ AtraiA platform } & Platform's founder and manager & $00: 41: 22$ & E1 \\
\cline { 2 - 4 } & Platform user & $00: 25: 03$ & E2 \\
\hline $\begin{array}{l}\text { Banco de Tempo } \\
\text { from Porto Alegre }\end{array}$ & Platform's founder and manager & $00: 24: 48$ & E3 \\
\cline { 2 - 4 } Garupa & Platform participant & $00: 15: 56$ & E4 \\
\hline Airbnb & Platform's founder and manager & $01: 16: 33$ & E5 \\
\hline Blablacar & Platform user (host and guest) & $00: 14: 51$ & E6 \\
\hline Dinneer & Platform user & $00: 12: 11$ & E7 \\
\hline
\end{tabular}

Source: Elaborated by the authors.

The analysis was performed based on the theoretical framework proposed by Wittmayer et al. (2019). Thus, for the purposes of the study presented 
here, the notion of coding was used, derived from an inspiration from the Grounded Theory (Strauss \& Corbin, 2008), according to which the data were analyzed line by line, constantly and encoded at each paragraph. Thus, the analytical relevance of any variable is not assumed until it appears as relevant. Based on this system, the data were cataloged (title/platform, narrator, year, and location/site) to perform a descriptive stage, seeking to identify evidence that illustrated the issues proposed by the framework. Thus, we first identify the content of the narratives of changes, contemplating the justification, the players, and the plot. Next, we analyzed the construction of narratives and, based on the identification of how narratives are constructed, it was possible to identify the main narratives. Finally, we analyze the role of these narratives. This analytical routine was performed for documental analysis, netnography, field notes from participant observation, and transcription of the interviews. Next, we present the results of this analysis, in which the context was discussed in light of the analysis of the narratives of changes in SE.

\section{ANALYSIS AND DISCUSSION OF RESULTS}

\subsection{Narrative content}

The content of the narratives presents three elements: justification, players, and plot. Justification for the emergence of SE seems to be the element of least controversy in the debate about the phenomenon. It is evident the emergence of SE in response to the economic crisis of 2008, in a debate that positions the phenomenon as a threat versus an opportunity for traditional companies. Combined with this, the internet was the main driver for the advance of SE (Stokes, Clarence, Anderson, \& Rinne, 2014). The players identified were SE companies, traditional economy companies, citizens who act as prosumers, government (with an important role in regulation), sector agencies, and consulting firms. The prosumers and the SE platforms are the protagonists of the change and also the main beneficiaries. The platform can also be understood by acting as a supporter of prosumers since it makes the transaction occur and works as a "support center" to the participating peers. Finally, the SE Plot appears differently, according to the platform's for-profit. For-profit platforms place SE as an income opportunity for the actors involved and bring challenges involving employment relations and the legality of activities. Still, in this type of platform, the narrative is constructed as a stimulus to society to pressure the government, seeking to "debureaucratise" 
the performance of these platforms. On the other hand, non-profit platforms, by presenting a narrative linked to the essence of sharing, provoke society to change the mentality, seeking a worldview focused on purpose and human relations that can lead to social transformations.

\subsection{Role of narratives}

We start from the three great roles of narratives in the processes of social change, suggested by Wittmayer et al. (2019): 1. changing scenarios; 2 . forming identity; 3 . guiding the action. We've identified the last two.

Narratives assume a role of forming the identity of both the individuals and a group as they consolidate. Based on the understanding of the possibilities of gains with SE (financial or not), the narratives construct it as a necessity of contemporaneity, being even used by companies as a legitimation strategy. By highlighting the benefits of financial gains, resulting in social practices based on entrepreneurship, job opportunity, or extra income, they generate individual empowerment. In this perspective, Biswas, Pahwa, and Sheth (2015) understand that the emergence of SE has made the path to self-work easier and, because of this, more people are becoming entrepreneurs. Consequently, the SE generates collective empowerment, interfering in an economic conjuncture, thus, becoming an option for society (initially as an additional income and, later, as the main income) and transforming the local economy, in the case of for-profit platforms. In the case of non-profit platforms, collective empowerment is based on a narrative of the establishment of relationships of trust and fraternity, transforming people's relationships, as illustrated in interviewee 2's statement: “[...] when you start to make the exchanges, you start to feel, in practice, how it brings benefits".

SE narratives also tend to guide actions, triggering the imagination of those who are part of it. Based on a context of uncertainty, the SE presents itself inducing the idea of a new possible future, generating expectations of more changes in the future of work and in new forms of autonomy and income generation (for-profit platforms); and also in a search for a more collaborative society and with a look at the collective (non-profit platforms). This point is highlighted in the comment brought in interview 4: "I believe that the Banco de Tempo and other collaborative or sharing economy initiatives are just the first step for us to come and change in the future".

The role of narratives as changing scenarios has not been identified. It can be highlighted that, based on the research carried out, the SE is not positioned as an expression of counterculture or a movement that fights against established cultural and institutional narratives. Non-profit platforms even 
present a narrative of searching for a change of mentality in society, in the sense of developing a sense of collectivity. However, this occurs in parallel to the current economic structure, as an alternative model, and not as a "flag" of struggle against the dominant structures.

\subsection{Constructing narratives}

The narratives produced differ in terms of the type of platform (forprofit or non-profit), and such divergence is the starting point for understanding the influence of the social-economic context on the transformative potential of SE.

\subsubsection{Identification on non-profit platforms}

Two main narratives were identified for non-profit platforms: "sense of community" and "equity", given the search for an alternative to the dominant economic model and its role of development and support to the local community (Figure 5.3.1.1).

(Figure 5.3.1.1)

EVIDENCE OF KEY NARRATIVES ON NON-PROFIT PLATFORMS

\begin{tabular}{|c|c|c|}
\hline $\begin{array}{c}\text { Main } \\
\text { narratives }\end{array}$ & Source & Evidence \\
\hline \multirow{3}{*}{$\begin{array}{l}\text { Sense of } \\
\text { community }\end{array}$} & Netnography & $\begin{array}{l}\text { "By helping each other, we renew communities of support, strength, } \\
\text { and trust. The community is built with roots, building trust, creating } \\
\text { networks" (TimeBanks USA, 2019). }\end{array}$ \\
\hline & Interview & $\begin{array}{l}\text { "[...] every opportunity I advertise the site so that people can know } \\
\text { and use this platform, which can benefit low-income people, with } \\
\text { financial difficulty, to acquire the objects they would like right. So } \\
\text { this creates a very big social impact, and somehow that's my } \\
\text { benefit... The satisfaction of the other is my benefit" (E2, 2019). }\end{array}$ \\
\hline & Report & $\begin{array}{l}\text { "Freecycle is another platform designed to encourage reuse rather } \\
\text { than discarding unwanted but still useful items. It has more than } \\
9 \text { million members worldwide in more than 5,000 local group } \\
\text { communities. It allows people to publish their unwanted products } \\
\text { online so that other interesting sites can pick them up and reuse } \\
\text { them. Freecycle has been around since } 2003 \text { and currently has } \\
62 \text { participating groups in NSW" (Deloitte, } 2017, \text { p. 16). }\end{array}$ \\
\hline
\end{tabular}

(continue)

3 https://timebanks.org/ 


\section{(Figure 5.3.1.1 (conclusion))}

\section{EVIDENCE OF KEY NARRATIVES ON NON-PROFIT PLATFORMS}

\begin{tabular}{|c|c|c|}
\hline $\begin{array}{c}\text { Main } \\
\text { narratives }\end{array}$ & Source & Evidence \\
\hline \multirow{3}{*}{ Equity } & Netnography & $\begin{array}{l}\text { "One hour = one credit; The 'one = one' rule is deeply rooted in the } \\
\text { idea that, regardless of whether we value what we do in different } \\
\text { ways, we share fundamental equality as human beings" (TimeBanks } \\
\text { USA, 2019). }\end{array}$ \\
\hline & Netnography & $\begin{array}{l}\text { "Our goal is to contribute to the reduction of inequality, valuing } \\
\text { diversity and care for the environment" (Evento Colaborametica, } \\
\text { 2018). }\end{array}$ \\
\hline & Interview & $\begin{array}{l}\text { "The Banco de Tempo is nothing more than a bank where the } \\
\text { currency is time. [...]. It doesn't account for all the differences } \\
\text { we have, but it helps a lot to make relationships more equitable" } \\
(E 3,2019) \text {. }\end{array}$ \\
\hline
\end{tabular}

Source: Elaborated by the authors.

We evaluated platforms in the contexts of Brazil and the United States, and, in both, the platforms present an attempt to transform society in favor of a future of better social relations, generating a relationship of trust and brotherhood between people. In the United States, TimeBanks USA's mission is to "promote equality and build community solidarity economies through inclusive exchanges of time and talent". In Brazil, it is illustrated in the reports of interviews below.

We had in mind that people could let go of things that they have leaning against their homes, that are unused, that can suddenly be very useful to other people who don't. But we think a little about who doesn't even have internet access. [...] The issue of social inclusion in technology is something that we have to rethink well. I think they [users] see a more selfless [sic] view, more than the issue of sustainability $(\mathrm{E} 1,2019)$.

The benefits, for me, are social, much more social than personal [...] using this platform, which can benefit low-income people with financial difficulty to acquire the objects they would like. So this creates a

${ }^{4}$ http://colaboramerica.org 
very big social impact, and somehow that's my benefit... The satisfaction of the other is my benefit (E2, 2019).

And I think, too, the sharing economy demands and reminds us that it is necessary that, we humans, we rescue trust in each other, right? And one of the basic premises to enjoy the sharing economy is trust; you trust the person who will offer you the services right, trust when you get in a car, trust when you enter a house or the apartment that you rented by Airbnb, you have to trust (E2, 2019).

[...] the Banco de Tempo kind of eliminates social exclusion because it's not going to see for whom you're doing something. Whether a person is rich or poor, she's taking the time to give you credit there; she's in. So this brings a horizontality with respect to the sharing economy [...] We can exchange more fluidly, with more freedom, without inequalities, and I also think it stimulates a sense of unity within a community (E4, 2019).

Even the reports that focused on analyzing the for-profit platforms mention the role played by non-profit platforms, demonstrating that there is no deliberate distinction regarding the social-economic context, reinforcing the promotion of the sense of community among participants.

The platform [Chuffed] does not receive a commission from donations; therefore, charities can keep $100 \%$ of what is raised. Instead, the platform asks donors to pay an optional additional fee to keep the platform running (Deloitte, 2017, p. 13).

By positioning themselves as an alternative to the conventional economy, these platforms occupy a space aimed at serving the local community, generating social benefits for the inserted actors:

I didn't see the question of being able to make a lot of money. Being able to sustain myself and work sustainability to spread these concepts, you know, in our community, is what interests me the most (E1, 2019).

[...] I acquired several books [on the platform]; these books went to Dona Tania. Ms. Tania put them in the library, she said there's a library there in the community. So, those books will impact the lives of those teenagers, of those children (E2, 2019). 
Designed to increase our individual and community well-being, Timebanking takes place through member exchanges as they provide and receive services to each other or through group and community activities and projects (TimeBanks USA, 2019) ${ }^{5}$.

Interpersonal and cultural relationships are affected in SE, with people sharing cultures, needs, demands, with real people engagement, shaping relationships. Individuals' behaviors are impacted by finding opportunities that generate social integration and access to goods not available in their lives up to a certain time (Dillahunt \& Malone, 2015). However, these relationships are still local and restricted to a niche, clearly positioned as an alternative to the dominant economic model, regardless of the socialeconomic context in which they are inserted, as evidenced by the Banco de Tempo of the United States and Brazil.

Co-production requires a healthier relationship and mutual support between the two types of economy (central and monetary). TimeBanks USA is committed to exploring more deeply the relationship between these two economies (TimeBanks USA, 2019).

The format that it $[\mathrm{BT}]$ has in Brazil is transitory. It is a way for people to remember and exercise other ways of relating economically, but there will come a time when they will not need someone, something, or an external structure for these relationships to happen; they will occur in a fluid, automatic, natural way, they will be composing themselves through the encounters and through the senses that people build together, about these new or old ways of relating economically (E3, 2019).

In non-profit platforms, the economic and social context does not influence the transformative potential guided by SE. The main narratives: 'sense of community and 'equity are presented in both contexts, positioning themselves as an alternative to the current economic model, but without any mention about replacing it.

\subsubsection{Identification on for-profit platforms}

If, on the one hand, the narratives of non-profit platforms are unique, regardless of context, on the other hand, in for-profit platforms, the identified

5 Retrieved from: https://timebanks.org/. 
narratives present nuances sensitive to the economic and social context, influencing their potential for transformation of SE. The for-profit platforms presented two main narratives: "income opportunity" and "need for regulation". The "income opportunity", in less favored economic and social contexts, is seen in SE as a principal income opportunity, representing a possible path to social mobility. In more favored contexts, SE is only an extra source of income (Figure 5.3.2.1).

(Figure 5.3.2.1)

EVIDENCE OF THE NARRATIVE "INCOME OPPORTUNITY" FOR FOR-PROFIT PLATFORMS

\begin{tabular}{|c|c|c|c|c|}
\hline \multirow{2}{*}{$\begin{array}{c}\text { Main } \\
\text { narrative }\end{array}$} & \multirow{2}{*}{ Source } & \multirow{2}{*}{ Evidence } & \multicolumn{2}{|c|}{$\begin{array}{l}\text { Social-economic } \\
\text { context of the player }\end{array}$} \\
\hline & & & $\begin{array}{l}\text { Less } \\
\text { favored }\end{array}$ & $\begin{array}{c}\text { Most } \\
\text { favored }\end{array}$ \\
\hline \multirow[t]{2}{*}{$\begin{array}{l}\text { Income } \\
\text { opportunity - } \\
\text { "main income" }\end{array}$} & Report & $\begin{array}{l}\text { "The sharing economy has transformed the } \\
\text { employment market to the benefit of millions } \\
\text { of workers. It is empowering a new class of } \\
\text { micro-entrepreneurs who are financially } \\
\text { rewarded for sharing their expertise, resources, } \\
\text { and services. It has led to a hike in income levels } \\
\text { of individuals, especially those in the low } \\
\text { socio-economic segment [...]. The entry of } \\
\text { platforms will be a social benefit by introducing } \\
\text { members of the lower social strata to the latest } \\
\text { technology and also by familiarizing them with } \\
\text { English, which would increase their overall } \\
\text { employment and social prospects" (Biswas, } \\
\text { Pahwa, \& Sheth, 2015, p. 18). }\end{array}$ & $x$ & \\
\hline & Interview & $\begin{array}{l}\text { "There is the case of Betinho [...]. He gave a } \\
\text { statement that changed his life [...]. And he } \\
\text { started working, working, working, working, } \\
\text { working. Then he said that he saw that he had } \\
\text { changed when one day he came home and the } \\
\text { woman came to say: 'Wow, Beto, you're looking } \\
\text { really good' [...]. Because every day he came } \\
\text { home with money. He started paying his bills. } \\
\text { [...]'I work at Garupa. The heavy-duty work } \\
\text { is over"' (E5, 2019). }\end{array}$ & $x$ & \\
\hline
\end{tabular}

(continue) 


\section{(Figure 5.3.2.1 (conclusion))}

EVIDENCE OF THE NARRATIVE "INCOME OPPORTUNITY" FOR FOR-PROFIT PLATFORMS

\begin{tabular}{|c|c|c|c|c|}
\hline \multirow{2}{*}{$\begin{array}{c}\text { Main } \\
\text { narrative }\end{array}$} & \multirow{2}{*}{ Source } & \multirow{2}{*}{ Evidence } & \multicolumn{2}{|c|}{$\begin{array}{l}\text { Social-economic } \\
\text { context of the player }\end{array}$} \\
\hline & & & $\begin{array}{l}\text { Less } \\
\text { favored }\end{array}$ & $\begin{array}{c}\text { Most } \\
\text { favored }\end{array}$ \\
\hline \multirow{3}{*}{$\begin{array}{l}\text { Income } \\
\text { opportunity - } \\
\text { "additional } \\
\text { income" }\end{array}$} & Report & $\begin{array}{l}\text { UK: "Over half (54 percent) saw their Sharing } \\
\text { Economy activity as just a way of making } \\
\text { some extra money, rather than as a formal } \\
\text { employment status" (Rahim et al., 2017, p. 4). }\end{array}$ & & $x$ \\
\hline & Report & $\begin{array}{l}\text { USA: "Individuals can earn flexible income from } \\
\text { underused assets, and consumers can gain } \\
\text { access to expensive things they may otherwise } \\
\text { prefer not to own" (Thilmany, 2016, p. 1). }\end{array}$ & & $x$ \\
\hline & Netnography & $\begin{array}{l}\text { "[...] it's a way to earn an extra income by doing } \\
\text { things I really like" (Testimonial host Lyn, } \\
\text { Puerto Rico, in Airbnb.com, 2019). }\end{array}$ & & $x$ \\
\hline
\end{tabular}

Source: Elaborated by the authors.

In countries with weaker economic systems and, consequently, a population in greater vulnerability, the individual is placed as a "micro-entrepreneur", facilitating the creation of new markets and activities that did not previously exist. Within the role of narratives, it can be said that they guide the action, triggering the imagination, by describing a possible future. The question that remains open is whether entrepreneurship really presents itself as an option; or if it simply represents the absence of other options. The role of forming the identity of the actors directly related to their empowerment is also presented in contexts of greater vulnerability:

We have a host in Maragogi, on the edge of the beach, a riverside on the beach, in a village there in Alagoas, which is making money with Dinneer. There's another person in Ushuaia, Argentina, at the end of the world, also making money from Dinneer. The money's in his house. So we're talking about distributing wealth; it's not just thinking about a business. We end up taking wealth to places where it does not arrive (E8, 2019).

The economic benefits linked to SE beckon the possibility of access to a better future. In this image, the player does not put himself in a situation of 
precarious work relations since he sees himself as an "entrepreneur" or selfemployed. Going further, the SE provided him with something that the traditional industry did not provide. However, these voices, which signal the empowerment and distribution of wealth, are not homogeneous because they belong to actors who own the platforms. In the prosumers' statements, these potentially transformative impacts did not present themselves. The SE as the first income is directly proportional to the context of vulnerability of the actors involved. Here, a "romantic" narrative of the phenomenon seems to reside: if society has little or no access to minimum conditions of survival, the offer of some alternative should not be confused with a real opportunity.

In contexts of less vulnerability, in which the actors already have a first income, the SE presents itself as an opportunity for an extra income, as illustrated in Figure 5.3.2.1, in reports based on the context of the United States, Great Britain, and in the netnography performed.

These actors, because they have a main source of income, do not understand that they should pay tax for income from the SE, precisely because it is extra and because they consider it not significant. When placed as a secondary activity, any type of precariousness associated with work has less impact on the individual. Access, as a mechanism of social change, is not relevant in this context because this income does not change the standard of living of those who are inserted in it. In Britain, for example, individuals who did not associate their SE activity with formal employment status, saying that the activity did not involve a "job" but was seen as a facilitator (Rahim et al., 2017). Such conclusions corroborate Ganapati and Reddick (2018) and Murillo et al. (2017) when they state that the biggest supporters of SE are the richest because they have idle assets available.

If the narrative "income opportunity" is presented differently due to the social-economic context, the same does not happen in the narrative "need for regulation". We highlight that this narrative was only identified in the reports given its eminently economic character (Figure 5.3.2.2), but it is intimately intertwined with the narrative of "income opportunity".

(Figure 5.3.2.2)

NARRATIVE EVIDENCE "NEED FOR REGULATION" FOR FOR-PROFIT PLATFORMS

\begin{tabular}{lcc}
\hline Main narrative & Source & Evidence \\
\hline $\begin{array}{l}\text { Need for } \\
\text { regulation }\end{array}$ & Report & $\begin{array}{l}\text { "Local, state and federal governments should regulate at least some } \\
\text { aspects of the sharing economy" (Thilmany, 2016, p. 6). }\end{array}$ \\
\hline
\end{tabular}




\section{(Figure 5.3.2.2 (conclusion)) \\ NARRATIVE EVIDENCE "NEED FOR REGULATION" \\ FOR FOR-PROFIT PLATFORMS}

\begin{tabular}{|c|c|c|}
\hline Main narrative & Source & Evidence \\
\hline \multirow{3}{*}{$\begin{array}{l}\text { Need for } \\
\text { regulation }\end{array}$} & \multirow{3}{*}{ Report } & $\begin{array}{l}\text { "The forum brought together government decision-makers, sharing } \\
\text { economy companies, and leading experts in the field to discuss how } \\
\text { to approach the regulatory challenges of the sharing economy" } \\
\text { (Holmes \& McGuinty, 2015, p. 4). }\end{array}$ \\
\hline & & $\begin{array}{l}\text { "The rapid growth of some of these platforms has provoked } \\
\text { considerable debate about the application of state and local } \\
\text { regulations to these platforms and to the suppliers who use them. } \\
\text { [...] On the one hand, appropriate regulatory measures can protect } \\
\text { consumers, promote public safety, and meet other legitimate } \\
\text { government targets. On the other hand, unnecessary or excessive } \\
\text { regulation can suppress disruptive innovation [...] Legislators and } \\
\text { regulators must balance these competing considerations" (Ramirez, } \\
\text { Ohlhausen, \& McSweeny, 2016). }\end{array}$ \\
\hline & & $\begin{array}{l}\text { "Experience to date suggests that policy-making that effectively } \\
\text { leverages the benefits of the sharing economy requires the creation } \\
\text { of the right enabling framework based on a set of guiding principles" } \\
\text { (Gawel, Machur, \& Pennington, 2016, p. 13). }\end{array}$ \\
\hline
\end{tabular}

Source: Elaborated by the authors

The growth of SE is facilitated by the government's deregulation deficiency. On the one hand, the lack of regulation facilitates the access of individuals in greater economic vulnerability to a source of income. On the other hand, the lack of regulation creates voids that can be filled with precarious employment relationships between prosumers and for-profit platforms. In this sense, many reports suggest an intelligent regulation system. According to a report by Deloitte (2017), smart regulation was able to regulate and expand the growth of SE in the Australian state of New South Wales. The government of Ontario (Canada) has set out actions for SE companies to meet existing obligations, but ensuring that these obligations reflect a changing economy from traditional business models to business models from new technologies (Holmes \& McGuinty, 2015). However, the issue of regulation is still much discussed and does not represent a consensus on the level to be established. Going further, an intelligent regulation system for whom? We question the lack of a mention to supply the paradox of income opportunity and the precariousness of work relationships since the income opportunity 
presents itself to some actors as a main alternative. The European Commission (2016, p. 6), for example, states that

[...] thresholds, when set in a reasonable manner, can be a useful indicator and contribute to creating a clear regulatory framework for non-professional providers. The level of control or influence exercised by the platform on the provider of these services is generally of great importance.

In a world of essentially capitalist markets, they very easily use the deficiency of regulation to incorporate gains. This statement reinforces Morozov (2013), which points out that SE exacerbates the worst practices of capitalism. The narratives that place SE as a path that provides faster financial growth and with less bureaucracy than the traditional industry should be analyzed more critically. The lower bureaucracy is due to the lack of regulation on the part of the government. The absence of regulation is not necessarily beneficial, especially in economic contexts of the greater vulnerability of society.

\section{FINAL REMARKS}

Through the analysis of the narratives of change, it is evident that the type of platform - with or without profit - is determinant in the construction of narratives. On for-profit platforms, SE is characterized as an income opportunity in the existing economy, while the narratives around the nonprofit SE place it as an alternative to the traditional economy. Our study points out that the advance of SE causes important externalities. There are indications that those who benefit the most economically are the holders of the platforms and users who see in the SE an opportunity for extra income, and this worsens in social-economic contexts of greater vulnerability.

In view of our objective, the main contribution of this study is the difference in the transformative potential identified in SE according to the social-economic context of the player. In contexts of greater economic vulnerability, the income opportunity means the individual's first income, which could lead to social mobility, considering the access provided to the individual. However, the lack of regulations seems to lead to greater vulnerability, reinforcing that the performance in the sharing economy is due to the lack of employment options in traditional businesses. Thus, we reinforce 
the perspective already identified in the literature, which places SE as a mechanism for worsening social inequality. In economic contexts of lower vulnerability, the income opportunity is presented as a source of additional income, not being determinant for the survival of the individual. This difference in the understanding of the form of income is not presented in the narrative of regulation of the sharing economy, demonstrating that regulatory concern does not represent a look at who is placed as a workforce of the SE. This finding reinforces the possibility of SE being a solution that generates social mobility not only in the short term but also in the long term, which can increase social inequality.

Non-profit platforms symbolize a search for a more collaborative society with a look at the collective, providing a means of access to goods and services to actors in a more inclusive and equity-based way. By presenting a declared narrative of equity and a sense of community, they position themselves as an alternative to the dominant economic model. In non-profit platforms, the economic and social context does not influence the transformative potential of SE in light of the narratives that build it.

This study contributes to academia by applying a theoretical framework from social innovation to analyze the narratives of SE and its transformative potential. Clearly, for-profit platforms little (or nothing) are part of the phenomenon of social innovation as a transformative process. In addition, we deepened and evidenced the perception of the different actors involved in the SE. As a contribution to the practice, we can highlight the effects of the application of the SE in different economic contexts, highlighting the role of governments and regulators for a healthy development of the potential of this new economy.

This research has limitations that suggest directions for future studies. Although we have tried to use data that comprehensively contemplated the contexts of SE, we can highlight as limitations of this study the focus of the interviews with actors allocated in the Brazilian reality. Thus, as future research, it is possible to evolve in discussion with the analysis of primary data from different economic contexts. Another suggestion of future research is to seek to understand the effect of regulatory actions with longitudinal research. 


\section{ECONOMIA COMPARTILHADA E OS CONTEXTOS ECONÔMICOS E SOCIAIS: MERCENARISMO OU BEM COMUM?}

) RESUMO

Objetivo: O objetivo desta pesquisa foi compreender como os contextos econômicos e sociais influenciam no potencial transformador da economia compartilhada (EC).

Originalidade/valor: A literatura referente ao tema da EC ainda é repleta de incertezas. Entre elas, verificamos que há um paradoxo entre a geração de benefícios sociais à comunidade e o aumento da desigualdade social. Design/metodologia/abordagem: Os dados foram coletados por meio de análise documental, netnografia, observação participante e entrevistas. A partir da coleta, analisaram-se os dados à luz do framework teórico proposto por Wittmayer et al. (2019) para o exame de narrativas ligadas à inovação social.

Resultados: As narrativas produzidas diferem quanto ao tipo de plataforma (com e sem fins lucrativos). Verificamos que, nas plataformas sem fins lucrativos, os contextos econômicos e sociais não influenciam no potencial transformador orientado pela EC, diferentemente das plataformas com fins lucrativos, nas quais a narrativa "oportunidade de renda" é sensível ao contexto. As principais contribuições da pesquisa realizada consistem na utilização de um framework teórico da inovação social para analisar as narrativas da EC e na observação de diferenças contextuais sobre o fenômeno, o que deveria levar as plataformas e os governos (no seu papel regulador) a ter diferentes olhares sobre a EC. Concluímos que as narrativas da EC se apresentam diferentemente. As plataformas com fins lucrativos, pouco (ou nada), se inserem no fenômeno da inovação social como um processo transformador e, nos contextos de maior vulnerabilidade econômico social, podem ser um mecanismo de agravamento da desigualdade social.

\section{PALAVRAS-CHAVE}

Economia compartilhada. Inovação social. Narrativas. Contexto. Plataforma. 


\section{REFERÊNCIAS}

Avelino, F., Wittmayer, J., Dumitru, A., Longhurst, N., Hielscher, S., Weaver, P., Cipolla, C., Afonso, R., Kunze, I., Dorland, J., Elle, M., Pel, B., Strasser, T., Kemp, R., \& Haxeltine, A. (2015). Transitions towards new economies? A transformative social innovation perspective [Working Paper $n^{\circ} 3$ ].

Barnes, S. J., \& Mattsson, J. (2017). Understanding collaborative consumption: Test of a theoretical model. Technological Forecasting $\mathcal{E}$ Social Change, 118, 281-292. doi:10.1016/j.techfore.2017.02.029

Bastos, L. C., \& Biar, L. de A. (2015). Análise de narrativa e práticas de entendimento da vida social. Delta, 31, 97-126. doi:10.1590/0102-445 083363903760077

Belk, R. (2014). You are what you can access: Sharing and collaborative consumption online. Journal of Business Research, 67, 1595-1600. doi:10.1016/j. jbusres.2013.10.001

Benoit, S., Baker, T. L., Bolton, R. N., Gruber, T., \& Kandampully, J. (2017). A triadic framework for collaborative consumption (CC): Motives, activities and resources \& capabilities of actors. Journal of Business Research, 79, 219-227. doi:10.1016/j.jbusres.2017.05.004

Biswas, R., Pahwa, A., \& Sheth, M. (2015). The rise of the sharing economy: The Indianlandscape. Kolkata: Ernst \& Young LLP. doi:10.1017/CBO97811074153 24.004

Cockayne, D. G. (2016). Sharing and neoliberal discourse: The economic function of sharing in the digital on-demand economy. Geoforum, 77, 73-82. doi:10.1016/j.geoforum.2016.10.005

Cohen, B., \& Kietzmann, J. (2014). Ride on! Mobility business models for the sharing economy. Organization \& Environment, 27(3), 279-296. doi:10.11 $77 / 1086026614546199$

Costello, L., McDermott, M. L., \& Wallace, R. (2017). Netnography: Range of practices, misperceptions, and missed opportunities. International Journal of Qualitative Methods, 16(1), 1-12. doi:10.1177/1609406917700647

Comissão Europeia (2016). Comunicação da comissão ao parlamento europeu, ao conselho, ao comité económico e social europeu e ao comité das regiões. Bruxelas, Bélgica: Comissão Europeia.

Czarniawska, B. (2000). The uses of narrative in organization research. London: Sage Publications. 
Daunorienè, A., Drakšaitė, A., Snieška, V., \& Valodkienė, G. (2015). Evaluating sustainability of sharing economy business models. Procedia Social and Behavioral Sciences, 213, 836-841. doi:10.1016/j.sbspro.2015. 11.486

Davidson, A., Reza, M., \& Laroche, M. (2018). Materialism and the sharing economy: A cross-cultural study of American and Indian consumers. Journal of Business Research, 82, 364-372. doi:10.1016/j.jbusres.2015.07.045

Davis, J. (2002). Narrative and social movements. Albany: State University of New York Press.

De Fina, A., \& Georgakopoulou, A. (2008). Analysing narratives as practices. Qualitative Research, 8(3), 379-387. doi:10.1177/1468794106093634

Deloitte (2017). Developments in the collaborative economy in NSW. Sidney: Deloitte Touche Tohmatsu.

Dillahunt, T. R., \& Malone, A. R. (2015). The promise of the sharing economy among disadvantaged communities. Annual ACM Conference on Human Factors in Computing Systems, Seoul, Korea, 33. doi:10.1145/2702123.2702189

Dreyer, B., Lüdeke-Freund, F., Hamann, R., \& Faccer, K. (2017). Upsides and downsides of the sharing economy: Collaborative consumption business models' stakeholder value impacts and their relationship to context. Technological Forecasting \& Social Change, 125, 87-104. doi:10.1016/j.techfore. 2017.03.036

Dudley, G., Banister, D., \& Schwanen, T. (2017). The rise of uber and regulating the disruptive innovator. The Political Quarterly, 88(3), p. 492-499. doi:10.1111/1467-923X.12373

Frenken, K., \& Schor, J. (2017). Putting the sharing economy into perspective. Environmental Innovation and Societal Transitions, 23, 3-10. doi:10.1016/j. eist.2017.01.003

Ganapati, S., \& Reddick, C. G. (2018). Prospects and challenges of sharing economy for the public sector. Government Information Quarterly, 35(1), 77-87. doi:10.1016/j.giq.2018.01.001

Gawel, A., Machur, W., \& Pennington, J. (2016). Understanding the sharing economy. In World Economic Forum. doi:10.14512/OEW310141

Gerwe, O., \& Silva, R. (2018). Clarifying the sharing economy: Typology, antecedents, and effects. Academy of Management Perspectives, 34(1), 65-96. doi:10.5465/amp.2017.0010

Gil, A. C. (2008). Métodos e técnicas de pesquisa social (6a ed.). São Paulo: Atlas. doi:10.1590/S1677-54492006000400001 
Guo, Y., Xin, F., Barnes, S. J., \& Li, X. (2018). Opportunities or threats: The rise of Online Collaborative Consumption (OCC) and its impact on new car sales. Electronic Commerce Research and Applications, 29, 133-141. doi:10. 1016/j.elerap.2018.04.005

Habibi, M. R., Davidson, A., \& Laroche, M. (2017). What managers should know about the sharing economy. Business Horizons, 60, 113-121. doi:10.10 16/j.bushor.2016.09.007

Holmes, A., \& McGuinty, L. (2015). Harnessing the power of the sharing economy: Next steps for Ontario. Ontario: Ontario Chamber of Commerce.

Hou, L. (2018). Destructive sharing economy: A passage from status to contract. Computer Law \& Security Review, 34(4), 965-976. doi:10.1016/j.clsr. 2018.05.009

Howaldt, J., \& Schwarz, M. (2016). Social innovation and its relationship to social change: Verifying existing social theories in reference to social innovation and its relationship to social change. Dortmund University. Dortmund, Alemanha.

Kovacs, P. (2017). Sharing economy: Implications for the insurance industry in Canada. Ontario: The Insurance Institute of Canada.

Kozinets, R. (2015). Netnography: Redefined (2nd ed.). Thousand Oaks, CA: Sage.

Lazarevic, D., \& Valve, H. (2017). Narrating expectations for the circular economy: Towards a common and contested European transition. Energy Research \& Social Science, 31, 60-69. doi:10.1016/j.erss.2017.05.006

Milanova, V., \& Maas, P. (2017). Sharing intangibles: Uncovering individual motives for engagement in a sharing service setting. Journal of Business Research, 75, 159-171. doi:10.1016/j.jbusres.2017.02.002

Mont, O., Neuvonen, A., \& Lähteenoja, S. (2014). Sustainable lifestyles 2050: Stakeholder visions, emerging practices and future research. Journal of Cleaner Production, 63, 24-32. doi:10.1016/j.jclepro.2013.09.007

Morozov, E. (2013). The "sharing economy" undermines workers' rights. The Financial Times. Retrieved from https://www.ft.com/content/92c3021c34c2-11e3-8148-00144feab7de

Muñoz, P., \& Cohen, B. (2017). Mapping out the sharing economy: A configurational approach to sharing business modeling. Technological Forecasting \& Social Change, 125, 21-37. doi:10.1016/j.techfore.2017.03.035

Murillo, D., Buckland, H., \& Val, E. (2017). When the sharing economy becomes neoliberalism on steroids: Unravelling the controversies. Technological Forecasting and Social Change, 125, 66-76. doi:10.1016/j.techfore.2017.05.024 
Palos-Sanchez, P. R., \& Correia, M. B. (2018). The collaborative economy based analysis of demand: Study of Airbnb case in Spain and Portugal. Journal of Theoretical and Applied Electronic Commerce Research, 13(3), 85-98. doi:10.4067/S0718-18762018000300105

Parente, R. C., Geleilate, J. M. G., \& Rong, K. (2018). The sharing economy globalization phenomenon: A research agenda. Journal of International Management, 24(1), 52-64. doi:10.1016/j.intman.2017.10.001

PricewaterhouseCoopers (2015). The sharing economy: Consumer intelligence series. Retrieved from https://www.pwc.com/us/en/industry/entertainment- media/publications/consumer-intelligence-series/assets/pwc-cissharing-economy.pdf

Rahim, N., Lepanjuuri, K., Day, F., Piggott, H., Hudson, R., \& Lubian, K. (2017). Research on the sharing economy. London: HM Revenue and Customs.

Ramirez, E., Ohlhausen, M. K., \& McSweeny, T. P. (2016). The "sharing" economy issues facing platforms, participants \& regulators, 3. Federal Trade Commission. Washington, EUA.

Ritzer, G. (2015). Prosumer capitalism. Sociological Quarterly, 56(3), 413-445. doi: $10.1111 /$ tsq. 12105

Schor, J. (2017). Does the sharing economy increase inequality within the eighty percent? Findings from a qualitative study of platform providers. Cambridge Journal of Regions, Economy and Society, 10(2), 263-279.

Schwandt, T. (2000). Three epistemological stances for qualitative inquiry: Interpretivism, hermeneutics, and social constructionism. In N. K. Denzin \& Y. S. Lincoln (Eds.), Handbook of qualitative research (2nd ed., pp. 189-213). Thousand Oaks, CA: Sage.

Stokes, K., Clarence, E., Anderson, L., \& Rinne, A. (2014). Making sense of the UK collaborative economy. London: Nesta Collaborative Lab.

Strauss, A., \& Corbin, J. (2008). Pesquisa qualitativa: Técnicas e procedimentos para o desenvolvimento de teoria fundamentada. (2a. ed.). Porto Alegre: Artmed.

Thilmany, J. (2016). Symposium on the sharing economy. In M. McCarthy (Ed.), Proceedings of the Symposia (pp. 1-8). Minnesota: Center for Transportation Studies, University of Minnesota.

Wittmayer, J., Backhaus, J., Avelino, F., Pel, B., \& Kunze, I. (2015). Narratives of change: How social innovation initiatives engage with their transformative ambitions [Working Paper $\mathrm{n}^{\circ}$ 4]. Transit: Transformative Social Innovation Theory. Rotterdam, The Netherlands. 
Wittmayer, J. M., Backhaus, J., Avelino, F., Pel, B., Strasser, T., Kunze, I., \& Zuijderwijk, L. (2019). Narratives of change: How social innovation initiatives construct societal transformation. Futures, 112, 102433. doi:10.1016/j. futures.2019.06.005

\section{AUTHOR NOTES}

Aline D. R. Lazzari, master from the Graduate Program in Business Administration, Pontifical Catholic University of Rio Grande do Sul (PUCRS); Maira C. Petrini, Ph.D. from the São Paulo School of Business Administration (Eaesp), Getulio Vargas Foundation (FGV); Ana C. A. A. Souza, Ph.D. from the School of Administration, Federal University of Rio Grande do Sul (UFRGS). Aline D. R. Lazzari is now a Ph.D. candidate in Management of the Graduate Program in Business Administration of PUCRS; Maira C. Petrini is now a professor at the Graduate Program in Business Administration of PUCRS; Ana C. A. A. Souza is now a post-doctoral fellow of the Graduate Program in Business Administration of PUCRS.

Correspondence concerning this article should be addressed to Aline D. R. Lazzari, Avenida Ipiranga, 6681, Building 50, Partenon, Porto Alegre, Rio Grande do Sul, Brazil, CEP 90619-900. E-mail: aline.r.lazzari@gmail.com

$\begin{array}{ll}\text { EDITORIAL BOARD } & \text { EDITORIAL PRODUCTION } \\ \begin{array}{l}\text { Editor-in-chief } \\ \text { Gilberto Perez }\end{array} & \begin{array}{l}\text { Publishing coordination } \\ \text { Jéssica Dametta }\end{array} \\ \text { Associate editor } & \text { Language editor } \\ \text { Janaina Macke } & \text { Daniel de Almeida Leão } \\ \text { Technical support } & \text { Layout designer } \\ \text { Vitória Batista Santos Silva } & \text { Emap } \\ & \text { Graphic designer } \\ & \text { Libro }\end{array}$

